\title{
Imidoylketene dimerization and rearrangement $\uparrow$
}

\author{
Lisa George, Paul V. Bernhardt, Klaus-Peter Netsch and Curt Wentrup* \\ Department of Chemistry, School of Molecular and Microbial Sciences, The University of \\ Queensland, Brisbane, Qld 4072, Australia.E-mail: wentrup@uq.edu.au
}

Received 13th August 2004, Accepted 27th September 2004

First published as an Advance Article on the web 4th November 2004

FVT of pyrroledione $\mathbf{1 0}$ affords the $\mathrm{NH}$-imidoylketene 11, which is characterized by its matrix isolation IR spectrum $\left(2117 \mathrm{~cm}^{-1}\right)$. On warming above $170 \mathrm{~K}, 11$ dimerizes to the oxazinone 13, the X-ray crystal structure of which is reported. Imidoylketene $\mathbf{1 1}$ also undergoes a (reversible) 1,3-phenyl shift to afford the detectable $\alpha$-oxoketenimine $\mathbf{1 6}$ $\left(2062 \mathrm{~cm}^{-1}\right.$ ) which at FVT temperatures above $400{ }^{\circ} \mathrm{C}$, isomerizes to 2-cyano-2-phenylacetophenone $\mathbf{1 8}$ (optimally at $700{ }^{\circ} \mathrm{C}$ ). Moreover, imidoylketene 11 can cyclize to azetinone 19, detectable at FVT temperatures up to $570{ }^{\circ} \mathrm{C}$, which undergoes cycloreversion to diphenylacetylene $\mathbf{2 0}$ and isocyanic acid (HNCO) 21. Energy profiles calculated at the B3LYP/6-31G** level for the unsubstituted imidoylketene, the diphenylimidoylketene 11 and the $N$-tert-butylimidoylketene are also reported.

\section{Introduction}

Ketenes are highly useful synthetic intermediates. ${ }^{1,2}$ Few ketenes are stable at room temperature, and in the absence of another reaction partner, they will dimerize. The dimers can be useful synthetic intermediates too, sometimes as reservoirs for the ketenes themselves via thermal dedimerization reactions. ${ }^{2,3} \alpha$ Oxoketenes $\mathbf{1}$ usually dimerize to form pyrones $\mathbf{2}$, formally in a [2+4] cycloaddition reaction involving a ketene $\mathrm{C}=\mathrm{C}$ bond as dienophile. Computational studies by Birney et al. have established the pseudopericyclic nature of related [2+4] cycloaddition reactions of ketenes. ${ }^{4} \mathrm{~A}$ second mode of dimerization of $\alpha$ oxoketenes involves the ketene $\mathrm{C}=\mathrm{O}$ bond as dienophile and appears to be favoured under conditions of steric hindrance of the $\mathrm{C}=\mathrm{C}=\mathrm{O}$ function. Thus, dipivaloylketene 1a dimerizes at room temperature to the 1,3-dioxinone 3a. Depending on reaction conditions, another mode of dimerization of $\mathbf{1 a}$, involving a straightforward addition of one molecule of the oxoketene to a pivaloyl $\mathrm{C}=\mathrm{O}$ group in the other, is also possible. Both dimers dedimerize on flash vacuum thermolysis (FVT) and thus can serve as reservoirs for ketene 1.,3 Methoxycarbonyl(pivaloyl)ketene 1b undergoes analogous dimerization across the ketene $\mathrm{C}=\mathrm{O}$ group to afford $\mathbf{3 b}$ (Scheme 1). ${ }^{5}$

Considerably less is known about the chemistry of imidoylketenes, largely because of the occurrence of facile isomerizations. Alkylimidoylketenes $\mathbf{4}$ carrying an $\alpha$-hydrogen atom undergo a 1,5-H shift to afford iminoacroleins $\mathbf{5}$, which may isomerise further. ${ }^{6}$ Imidoylketenes may also undergo 1,3shifts of the $\alpha$-substituents $\mathrm{X}$ to generate $\alpha$-oxoketenimines, ${ }^{7}$ as discussed below (eqn. (1)). Moreover, $N$-arylimidoylketenes 4 undergo a facile and preparatively useful cyclization to afford quinolones 6 , often in high yields. ${ }^{8}$

However, Chuche and coworkers achieved the isolation of the imidoylketene dimer $\mathbf{8 a}$ from $\mathbf{7 a}{ }^{9}$ This corresponds to the normal behaviour of the ketene $\mathrm{C}=\mathrm{C}$ bond acting as the dienophile. Very recently, Zhou and Birney have shown that the $N$-propyl analogue $\mathbf{7 b}$ undergoes $\mathrm{C}=\mathrm{C}$ addition to give $\mathbf{3 b}$ in $c a .15 \%$ yield, whereas the $N$-unsubstituted imidoylketene 7c affords the ketene $\mathrm{C}=\mathrm{O}$ adduct 9 in $c a .7 \%$ yield. ${ }^{10}$ Smalley and coworkers similarly reported the formation of 3-(2-aminophenyl)benzo[ $d][1,3]$ oxazin-1-one from the putative

$\dagger$ Electronic supplementary information (ESI) available: bond lengths and angles for the crystal structure of 13; unit cell of $\mathbf{1 3}$ in the crystal, showing intra- and intermolecular H-bonds; computational data for the species shown in Fig. 3-5. See http://www.rsc.org/suppdata/ $\mathrm{ob} / \mathrm{b} 4 / \mathrm{b} 412530 \mathrm{~d} /$

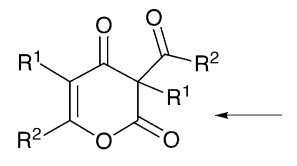

2

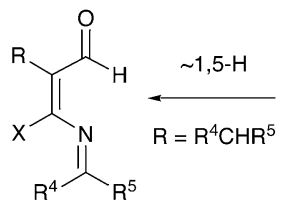

5

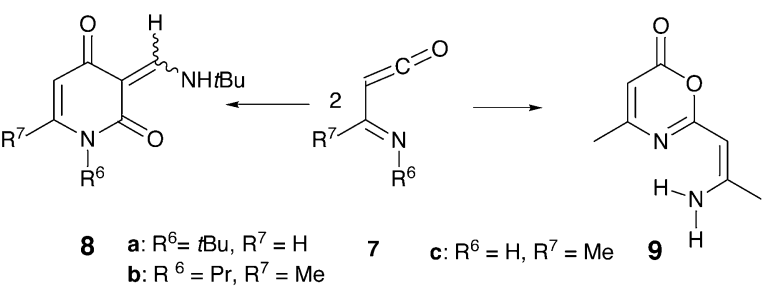

Scheme 1

imidoylketene by ring opening of benzazetinone. ${ }^{11}$ Detailed calculations of the transition structures for the two types of dimerization, involving addition to $\mathrm{C}=\mathrm{C}$ and $\mathrm{C}=\mathrm{O}$ bonds, respectively, demonstrated that both followed the minimum energy paths, and both were rationalized as pseudopericyclic reactions with planar transition states. ${ }^{10}$

Here we report the first direct observation of an $\mathrm{NH}$ imidoylketene (11), its dimerization involving the ketene $\mathrm{C}=\mathrm{O}$ bond as dienophile, its isomerization to the oxoketenimine, $\mathbf{1 6}$ and its cyclization to azetinone and cleavage of the latter.

\section{Results and discussion}

\section{Observation and dimerization of the imidoylketene}

FVT of the pyrrole-2,3-dione $\mathbf{1 0}$ at temperatures above $325^{\circ} \mathrm{C}$ resulted in the loss of $\mathrm{CO}$ (absorbing at 2138 and $2149 \mathrm{~cm}^{-1}$ ) and formation of the imidoylketene 11, characterized by an intense absorption at $2117 \mathrm{~cm}^{-1}$ in the IR spectrum (Ar matrix, $10 \mathrm{~K}$, Fig. 1) or at $2112 \mathrm{~cm}^{-1}$ as a neat solid at $77 \mathrm{~K}$. This absorption is 


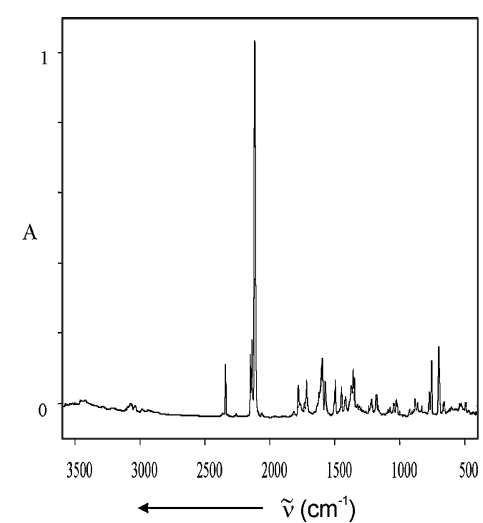

Fig. 1 FTIR spectrum of imidoylketene 11 (Ar matrix, $10 \mathrm{~K}$ ). The strongest absorption of $\mathbf{1 1}$ is at $2117 \mathrm{~cm}^{-1}$. Weaker bands at 2139 and $2149 \mathrm{~cm}^{-1}$ are due to $\mathrm{CO}$. When 11 is isolated without $\mathrm{Ar}$ at $70 \mathrm{~K}$, its main absorption is at $2112 \mathrm{~cm}^{-1}$, and the $\mathrm{CO}$ bands are missing. The band at $2340-2345 \mathrm{~cm}^{-1}$ is due to a minor amount of $\mathrm{CO}_{2}$. Absorbance $(A)$ in arbitrary units.

in good agreement with that computed at the B3LYP/6-31G** level, where the ketene stretch is the only calculated strong band $\left(2119 \mathrm{~cm}^{-1}, 904 \mathrm{~km} \mathrm{~mol}^{-1}\right)$. It is noteworthy that the calculated intensity of the $\mathrm{NH}$ band is very small $\left(3330 \mathrm{~cm}^{-1}, 1 \mathrm{~km} \mathrm{~mol}^{-1}\right)$, indeed this band is barely visible in the experimental spectrum. For further details of the calculated spectrum, see the electronic supplementary information. $\dagger$ Doubling of several bands in the experimental IR spectrum is probably due to the presence of more than one conformer of $\mathbf{1 1}$ in the matrix (see the calculated energy profile in Fig. 4 below).

The disappearance of the starting material 10 was complete at an FVT temperature of $c a .570{ }^{\circ} \mathrm{C}$. The ketene remained observable in the IR spectrum of the neat solid on warmup till above $190 \mathrm{~K}$, but its intensity decreased rapidly above $170 \mathrm{~K}$ due to dimerization. The dimer was isolated as lemonyellow rhombohedral crystals in a preparative FVT experiment under the same conditions. The IR spectrum of the matrixisolated dimer confirmed that this compound was formed on dimerization of the ketene above $170 \mathrm{~K}$. The ${ }^{13} \mathrm{C}$ NMR spectrum of the dimer indicated $\mathrm{Cl}$ symmetry. The elemental analysis and strong carbonyl absorption at $1700 \mathrm{~cm}^{-1}$ are consistent with a 1,3-oxazinone structure $\mathbf{1 3}$ (Scheme 2). Notably, the two NH protons appear at widely different chemical shifts, 5.3 and 10.4 ppm (both broad), which can be ascribed to one of them being engaged in a strong hydrogen bond to the oxazine nitrogen N3 in 13. This structure was confirmed by an X-ray crystal analysis (Fig. 2). The molecular backbone is virtually

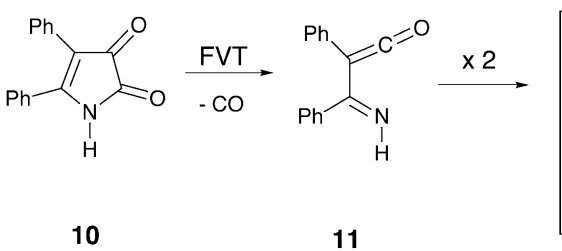<smiles></smiles>

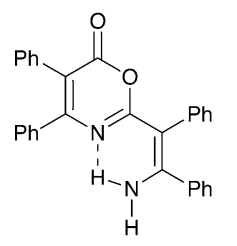

13

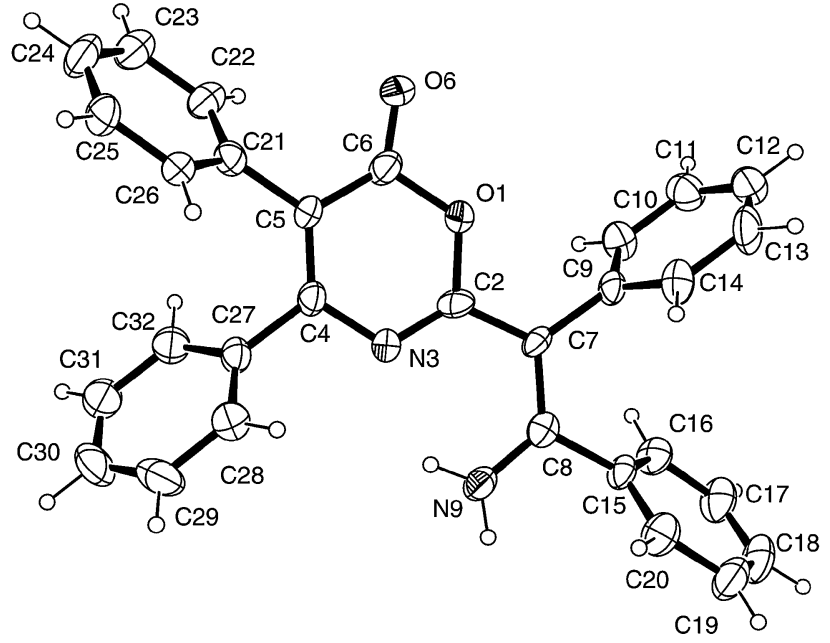

Fig. 2 ORTEP drawing of the crystal structure of $\mathbf{1 3}$.

planar, and the length of the intramolecular hydrogen bond is $1.99 \AA$. The other hydrogen atom of the amino group is involved in intermolecular $\mathrm{H}$-bonding with the $\mathrm{C}=\mathrm{O}$ group (O6) in a neighbouring molecule (see the ESI document). $\uparrow$ The formation of $\mathbf{1 3}$ is depicted in Scheme 2 as occurring via a [2+4] cycloaddition of one ketene molecule to the ketene $\mathrm{C}=\mathrm{O}$ group of another via the transition state 12TS. The calculations by Zhou and Birney demonstrate that this mode of dimerization is favoured in $\mathrm{NH}$-imidoylketenes due to a stabilization of the transition state by hydrogen bonding. ${ }^{11}$

FVT of the dimer 13 at $710{ }^{\circ} \mathrm{C}$ generated a small amount of a ketene absorbing at 2117 and $1659 \mathrm{~cm}^{-1}$. This is probably not ketene 11, but a new ketene formed by electrocyclic opening of the oxazinone ring in 13. We have investigated similar ring opening reactions of oxazinones ${ }^{12}$ and will publish them in a separate paper.

\section{Rearrangement}

It is known that $\alpha$-imidoylketenes $\mathbf{1 4}$ and $\alpha$-oxoketenimines $\mathbf{1 5}$ can interconvert by a 1,3 -shift of the $\alpha$-substituent, X (eqn. (1)). ${ }^{7}$

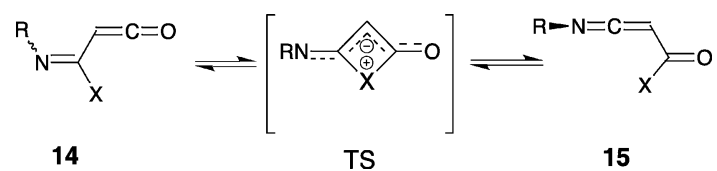

This reaction, analogous to the $\alpha$-oxoketene- $\alpha$-oxoketene interconversion, ${ }^{13}$ is particularly facile when $\mathrm{X}$ is an electron donating group which can interact favourably with the lowlying ketene LUMO $\left(\mathrm{NR}_{2}\right.$, OR, SR, and halogens). ${ }^{7,13,14}$ The dimethylamino group has the highest migratory aptitude, and the calculated activation barrier for $\mathbf{1 4} \rightarrow \mathbf{1 5}\left(\mathrm{X}=\mathrm{NMe}_{2}\right.$, $\mathrm{R}=\mathrm{R}^{\prime}=\mathrm{H}$ ) is $62 \mathrm{~kJ} \mathrm{~mol}^{-1} \cdot{ }^{7 \mathrm{~b}}$ Thus, this reaction will take place below room temperature. ${ }^{8}$ However, phenyl groups also undergo the 1,3-shift, typically under FVT conditions at temperatures around $970-1020 \mathrm{~K}$ in our apparatus. ${ }^{14}$ Further computational studies of the activation barriers for 1,3-shifts of a wide range of $\alpha$-substituents in $\alpha$-oxoketenes, $\alpha$-imidoylketenes and $\alpha$-oxoketenimines will be published. ${ }^{15}$

Further FVT experiments with matrix isolation, as well as GC-MS of the products, revealed that the intensity of the imidoylketene 11 diminished above $600{ }^{\circ} \mathrm{C}$, although it was still easily detectable at $850{ }^{\circ} \mathrm{C}$. The isomeric nitrile $\mathbf{1 8}$ was formed in its place. GC-MS analysis established the optimal temperature for formation of $\mathbf{1 8}$ as $700{ }^{\circ} \mathrm{C}$. Compound $\mathbf{1 8}$ was also identified by direct comparison of IR and NMR spectra with authentic material. ${ }^{16}$ A 1,5 -hydrogen shift in ketenimine 16 generates hydroxynitrile $\mathbf{1 7}$, which is a tautomer of $\mathbf{1 8}$. The 
existence of a solvent dependent mixture of two $Z / E$ isomers of enol 17 (17a and 17b) and ketone 18 has been reported, ${ }^{16 b, c}$ and our own NMR measurements support a ratio of $80: 8: 12$ of the two isomers of enol 17 and ketone 18 (DMSO- $d_{6}$ solution).

The ketenimine $\mathbf{1 6}$ was itself observable as a weak peak at $2062 \mathrm{~cm}^{-1}$ in the matrix IR spectra at very mild FVT temperatures, $350-500{ }^{\circ} \mathrm{C}$; the imidoylketene peak at $2117 \mathrm{~cm}^{-1}$ always remained the strongest peak. The reason for this is easily understood: although more ketenimine $\mathbf{1 6}$ should be formed in equilibrium with ketene $\mathbf{1 1}$ at higher temperatures, $\mathbf{1 6}$ is removed by isomerization to the nitrile 18. $N$-Unsubstituted ketenimines always tautomerize very easily to nitriles under FVT conditions, probably due to wall-catalyzed reactions..$^{17}$ An analogous reaction is known: generation of the ketenimine $7 \mathbf{a}$ above $700{ }^{\circ} \mathrm{C}$ results in elimination of isobutene and rearrangement to the corresponding ketenimine, which isomerizes to the tautomeric mixture of 3-oxopropionitrile and 3-hydroxyacrylonitrile. $6 a$

Furthermore, a second isomerization pathway with a lower activation energy also removes imidoylketene $\mathbf{1 1}$ and therefore also hinders any build-up of ketenimine 16: the cyclization of $\mathbf{1 1}$ to azetinone 19. The latter compound is observable by means of a weak peak at $1814 \mathrm{~cm}^{-1}$ in the matrix IR spectra only at the mildest FVT temperatures, $325-400{ }^{\circ} \mathrm{C}$. The weakness of this peak can be ascribed to a fragmentation to diphenylacetylene 20 and HNCO 21 (Scheme 3 and Fig. 4). Diphenylacetylene 20 was identified by GC-MS comparison with authentic material, its yield increasing with the temperature, and $\mathrm{HNCO}$ was identified by its characteristic matrix IR spectrum $\left(2259 \mathrm{~cm}^{-1}\right)$. The rearrangement and fragmentation modes leading to $\mathbf{1 8}$ and 20 became major reactions above $700{ }^{\circ} \mathrm{C}$. In addition, benzonitrile was always formed as a by-product in the high temperature range. The mechanism of formation of benzonitrile is not known.

We have calculated the energy profiles for the relevant rearrangements of the unsubstituted imidoylketene 11a (Fig. 3), the diphenylimidoylketene 11 (Fig. 4), and the $N$-tert-butylphenylmethylimidoylketene 11b (Fig. 5) at the B3LYP/6$31 G^{* *}$ level of theory. The energies of some of the species and transition states (TS2) were also computed at the 6311+G(3df,2p)//B3LYP/6-31G* level. Transition states were verified by intrinsic reaction coordinate calculations and imaginary vibrational frequencies (listed in the electronic supplementary information). $\dagger$ Part of the energy profile of the unsubstituted compounds, including ketene 11a, ketenimine 16a and azetinone 19a has been calculated previously at
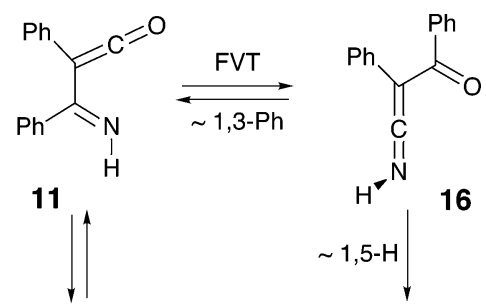<smiles>O=C1NC(c2ccccc2)=C1c1ccccc1</smiles><smiles>N#C/C(=C(/O)c1ccccc1)c1ccccc1</smiles><smiles>[V]C=[Te]</smiles>

17

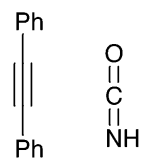<smiles>N#CC(C(=O)c1ccccc1)c1ccccc1</smiles>

20

21

Scheme 3

the MP4(SDQ)/6-31G**//MP2/6-31G** level. ${ }^{18}$ Our results (Fig. 3) are in good accord. The $N$-tert-butyl derivative in Fig. 5 is a model for the corresponding $N$-adamantyl-phenylmethyl derivative, which has been the subject of a previous investigation, where the thermal conversion of the $N$-adamantylimidoylketene to the $N$-adamantyloxoketenimine, the cyclization of $N$ adamantylimidoylketene to the $N$-adamantylazetinone (observed at 1814 and $1819 \mathrm{~cm}^{-1}$ in the Ar matrix IR spectrum), and the fragmentation of the latter to 1-phenyl-1-propyne and adamantyl isocyanate on FVT above $450{ }^{\circ} \mathrm{C}$ were observed. $14 c$

The energy profiles in Figs. 4 and 5 reveal that the activation barrier for the 1,3-phenyl shift interconverting imidoylketenes and oxoketenimines, $c a .150 \mathrm{~kJ} \mathrm{~mol}^{-1}$, is well within the expectations for FVT reactions. The calculated 1,3-shift barrier for a phenyl group in the otherwise unsubstituted imidoylketene is $186 \mathrm{~kJ} \mathrm{~mol}^{-1} \cdot{ }^{14}$ Thus, the two phenyl groups in $\mathbf{1 1}$ have a significant stabilizing effect on TS2 (Fig. 4). We have found that electron donating substituents (D) in the migrating phenyl group, and electron-withdrawing ones (W) in the other can lower this 1,3-phenyl migration barrier (TS2) in $\alpha$-oxoketenes $(\mathrm{Z}=\mathrm{O})$

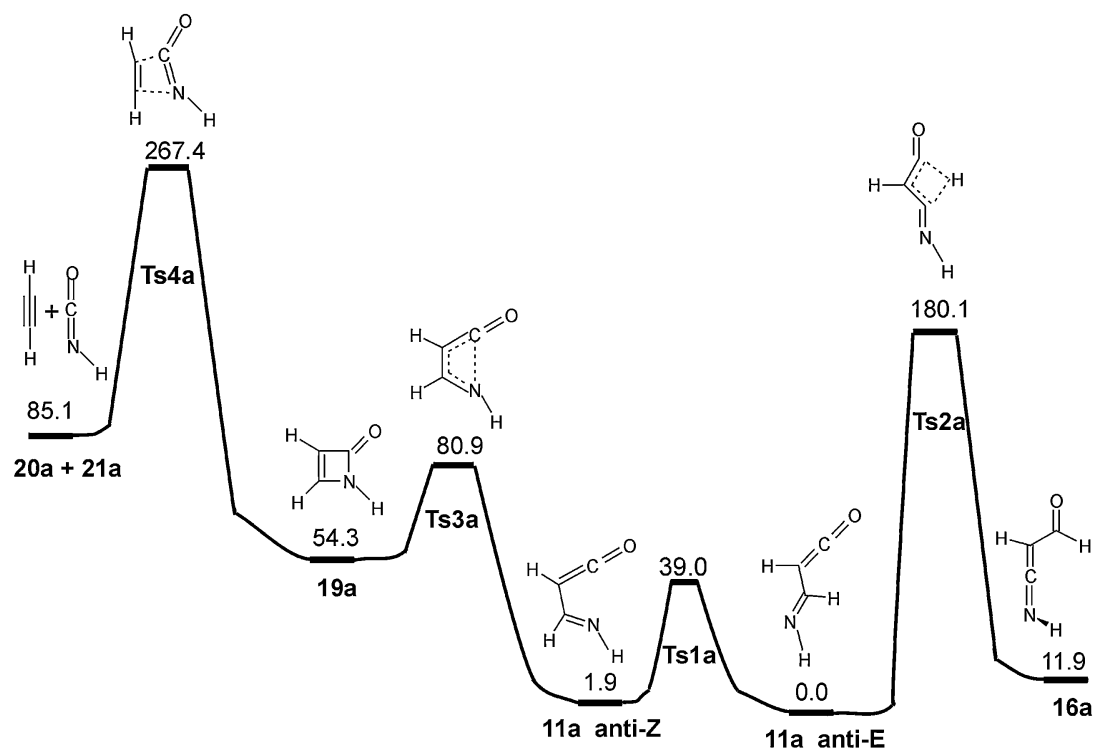

Fig. 3 Calculated energy profile for the rearrangements of the unsubstituted imidoylketene 11a at the B3LYP/6-31G** level of theory, corrected for zero-point vibrational energies (ZPVE). 


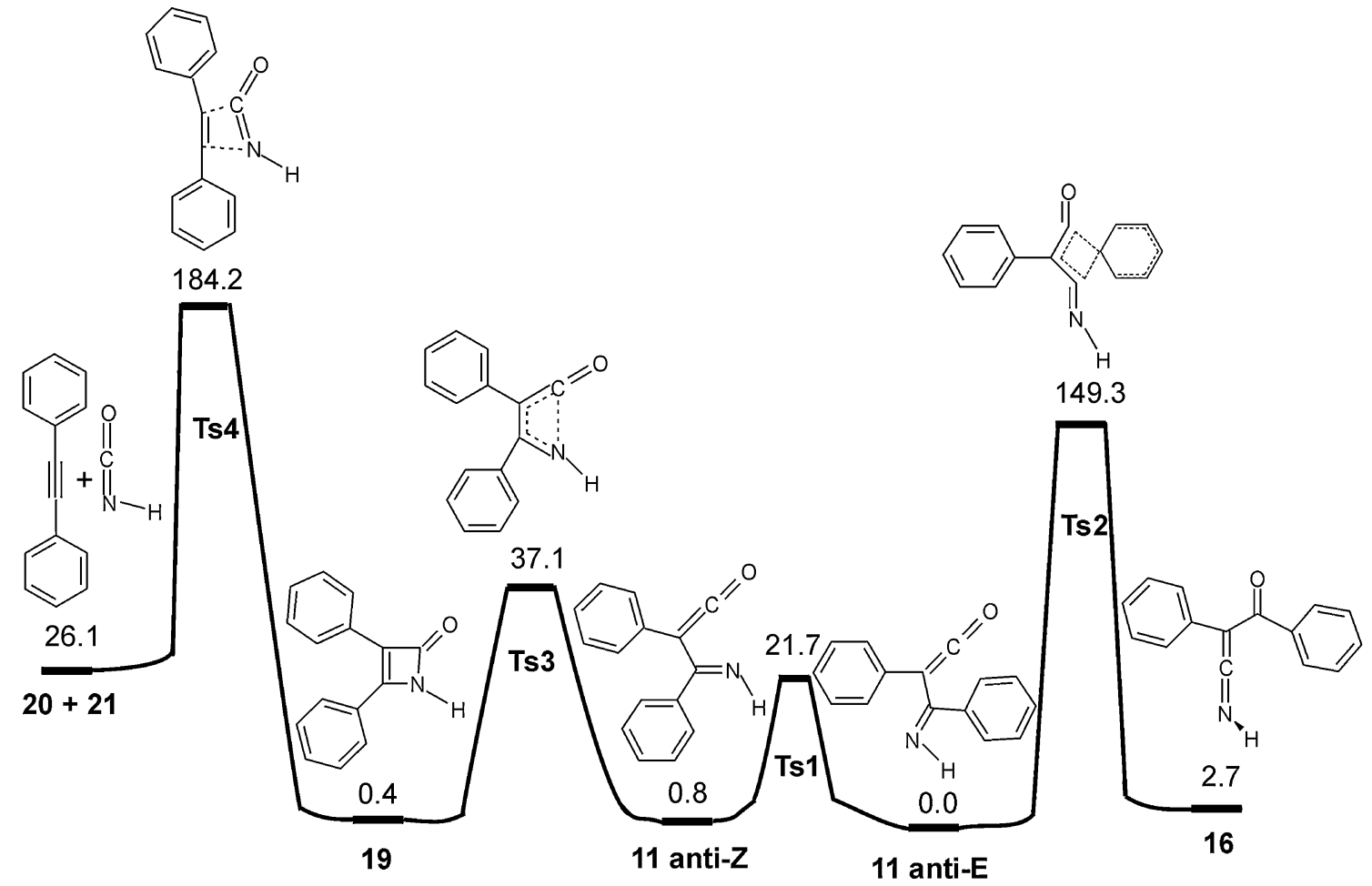

Fig. 4 Calculated energy profile for the rearrangements of the diphenylimidoylketene $\mathbf{1 1}$ at the B3LYP/6-31G** level of theory, corrected for ZPVE.

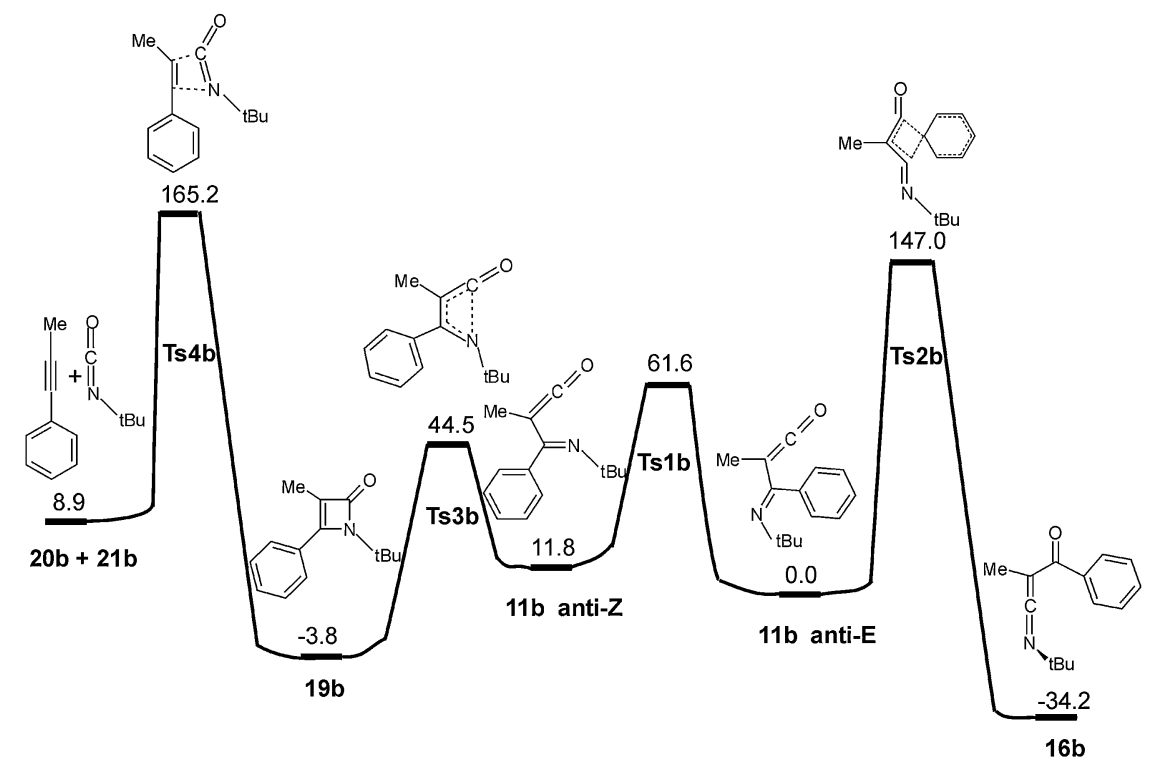

Fig. 5 Calculated energy profile for the rearrangements of the $N$-tert-butyl-phenylmethylimidoylketene $11 \mathrm{~b}$ at the B3LYP/6-31G** level of theory, corrected for ZPVE.

and imidoylketenes $(\mathrm{Z}=\mathrm{NR})$ further still.

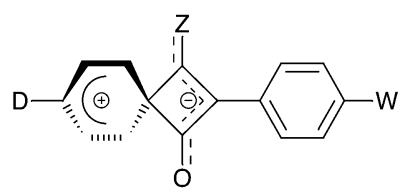

22

Comparison of the three energy profiles also reveals that an $\mathrm{N}$ tert-butyl group significantly destabilizes the ketene $\mathbf{1 1}$, probably due to steric strain, and conversely stabilizes the ketenimine isomer 16a, in agreement with the observation that the analogous $\mathrm{N}$-adamantylimidoylketene, underwent isomerization to the isolable $N$-adamantyloxoketenimine on FVT above $600{ }^{\circ} \mathrm{C} .14 c$ The phenyl substitution lowers the energy of the azetinone 19
(Fig. 4) very significantly, compared with the unsubstituted case (Fig. 3), and the $N$-tert-butyl group lowers this energy even further (Fig. 5) relative to the ketene 11. This is in accord with the finding that the $N$-adamantyl case was the only one where significant amounts of the azetinone could be matrix isolated. ${ }^{14 c}$ In the case of the diphenyl derivative, Fig. 4, 19, 11 and 16 all have very similar calculated energies, and only a trace of the azetinone 19 is observable under FVT conditions. As mentioned above, this can be ascribed to the cleavage to diphenylacetylene $\mathbf{2 0}$ and HNCO $\mathbf{2 1}$ as well as the isomerization of the easily formed ketenimine $\mathbf{1 6}$ to nitrile $\mathbf{1 8}$.

\section{Conclusion}

The $N H$-imidoylketene $\mathbf{1 1}$ is stable in the gas phase under conditions of FVT at moderate temperatures. It is also stable 
in the solid phase till $c a .-100{ }^{\circ} \mathrm{C}$, when it dimerizes to the 1,3-oxazinone 13. At FVT temperatures above $700{ }^{\circ} \mathrm{C}, \mathbf{1 1}$ undergoes a 1,3-phenyl shift to afford the $\mathrm{NH}$-ketenimine $\mathbf{1 6}$, which tautomerizes to nitrile $\mathbf{1 8}$. Imidoylketene $\mathbf{1 1}$ also cyclizes to azetinone 19, which fragments to diphenylacetylene and HNCO. All the processes are summarized in Scheme 4.

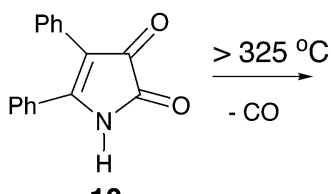<smiles>CN=C(C(=C=O)c1ccccc1)c1ccccc1</smiles><smiles>O=C(C(=C=Nc1ccccc1)c1ccccc1)c1ccccc1</smiles><smiles></smiles><smiles>O=C1C(=Cc2ccccc2)C(c2ccccc2)=C1c1ccccc1</smiles><smiles>N#CC(C(=O)c1ccccc1)c1ccccc1</smiles><smiles>N=C=O</smiles>

2021

Scheme 4

\section{Experimental}

The apparatus for FVT and matrix isolation was as previously reported. ${ }^{19}$ For GC-MS conditions see ref. 20. The pyrroledione 10 was prepared according to the literature, ${ }^{21} \mathrm{mp} 189$ $191{ }^{\circ} \mathrm{C}$; IR (KBr) $3270 \mathrm{~m}, 1735$ vs, 1700 vs, $1615 \mathrm{~m} \mathrm{~cm}^{-1} ;{ }^{13} \mathrm{C}$ NMR (DMSO- $d_{6}$ ) $\delta 159.9$ (C2), 183.3 (C3), 110.4 (C4), 163.6 (C5), 127.1, 128.3, 128.5, 128.6, 128.7, 129.1, 130.0, 132.3. 2Cyano-2-phenylacetophenone $\mathbf{1 8}$ was prepared according to the literature, ${ }^{22}{ }^{1} \mathrm{H}$ NMR (DMSO- $d_{6}$ ): the spectrum scanned till $15 \mathrm{ppm}$ showed peaks at $\delta 12.0(\mathrm{OH}), 11.6(\mathrm{OH})$ and $6.6(\mathrm{CH})$ in the integrated ratio $80: 8: 12$ corresponding to enol 17a : enol 17b : ketone 18, together with phenyl signals at $\delta 8.0$ to $7.0 ;{ }^{13} \mathrm{C}$ NMR (DMSO- $d_{6}$ ) $\delta 167.9$ (CO of main enol 17), 120.0 $(\mathrm{CN}$ of main enol 17a), $88.0(\mathrm{CH}$ of main enol17a), $87.8(\mathrm{CH}$ of isomeric enol 17b), 45.9 ( $\mathrm{CH}$ of ketone 18). The eight phenyl group signals of the major tautomer 17a are at 135.9, 132.9, 130.4, 128.4, 128.3 (two signals), 127.3, and 126.7 ( $c f$. ref. 16c). The assignment of the ${ }^{13} \mathrm{C}$ NMR data was supported by a DEPT spectrum.

\section{Crystallography}

Cell constants were determined by least-squares fits to the setting parameters of 25 independent reflections measured on an EnrafNonius CAD4 four-circle diffractometer employing graphitemonochromated Mo K $\alpha$ radiation $(0.71073 \AA)$ and operating in the $\omega-2 \theta$ scan mode. Data reduction was performed with the WinGX package. ${ }^{23}$ The structure of compound 13 was solved by direct methods with SHELXS and refined by full-matrix leastsquares analysis with SHELXL-97. ${ }^{24}$ All non-H atoms were refined with anisotropic thermal parameters. H-atoms attached to carbon were included in estimated positions using a riding model whereas and those attached to nitrogen were located from difference maps in the first instance then restrained also using a riding model. The drawing of the molecule (Fig. 2) was produced with ORTEP. ${ }^{25}$

\section{FVT and matrix isolation}

Pyrroledione $\mathbf{1 0}$ was sublimed into the FVT tube in a stream of $\mathrm{Ar}$ at $100{ }^{\circ} \mathrm{C}$ and thermolysed at temperatures ranging from $300-800{ }^{\circ} \mathrm{C}$. No reaction took place at $250{ }^{\circ} \mathrm{C}$. The products were isolated in an Ar matrix at $20 \mathrm{~K}$, and FTIR spectra were recorded at $c a .10 \mathrm{~K}$. A typical IR spectrum is shown in Fig. 2. Bands due to imidoylketene 11 are at $3456 \mathrm{vw}, 3071 \mathrm{vw}, 2117$ vs, $1595 \mathrm{~m}, 1575 \mathrm{~m}, 1498 \mathrm{~m}, 1361 \mathrm{~m}, 1351 \mathrm{~m}, 1180 \mathrm{w}, 1046884$ w, $862 \mathrm{w}, 775 \mathrm{w}, 756 \mathrm{~m}, 699 \mathrm{~m}, 655 \mathrm{w} \mathrm{cm}^{-1}$. Bands at 2138 and $2149 \mathrm{~cm}^{-1}$ are due to CO. The band at $2340-2345 \mathrm{~cm}^{-1}$ is due to a minor amount of $\mathrm{CO}_{2}$. Similar FVT of $\mathbf{1 0}$ using Ar as a carrier gas but with isolation at $70 \mathrm{~K}$ (i.e. without $\mathrm{Ar}$ and $\mathrm{CO}$ condensing), afforded 11 with its main absorption at $2112 \mathrm{~cm}^{-1}$, and the $\mathrm{CO}$ bands were missing under these conditions.

FVT temperatures above $700{ }^{\circ} \mathrm{C}$ caused formation of nitrile 18 in amounts increasing with the temperature and identified by GC-MS, IR and NMR comparison of the isolated product with the spectra of authentic material. Benzonitrile (identified by GC-MS and IR comparison with authentic material), diphenylacetylene (identified by GC-MS comparison with authentic material), and isocyanic acid $\mathrm{HNCO}$ (identified by its Ar matrix IR absorption at $2259 \mathrm{~cm}^{-1}$ ) were formed at the same time. GC retention times in min (relative peak abundance in \%) for the products formed at $700{ }^{\circ} \mathrm{C}$ : benzonitrile 2.95 (100), diphenylacetylene 9.4 (60), 2-cyano-2-phenylacetophenone $\mathbf{1 8}$ $11.6(75)$.

\section{4,5-Diphenyl-2-(1,2-diphenyl-2-aminoethenyl)- 1,3-ozaxin-6-one 13}

Pyrroledione 10 (300 $\mathrm{mg} ; 1.20 \mathrm{mmol})$ was sublimed into the FVT apparatus at $110{ }^{\circ} \mathrm{C}$ and thermolysed at $570{ }^{\circ} \mathrm{C}$ in the course of $2.5 \mathrm{~h}$. The product was collected in a liquid nitrogencooled U-tube and after the end of the experiment dissolved in acetone-methanol. Preparative thin layer chromatography on $\mathrm{SiO}_{2}$, eluting with methylene chloride, afforded a yellow solid (80 mg; 30\%), which crystallized as lemon-yellow rhombohedra from ethanol; $\mathrm{mp} 296{ }^{\circ} \mathrm{C} ;{ }^{1} \mathrm{H}$ NMR $\left(\mathrm{CDCl}_{3}, 400 \mathrm{MHz}\right) \delta 5.6$ (br, 1H), 7.05-7.40 (m, $20 \mathrm{H}), 10.4$ (br, $1 \mathrm{H}) ;{ }^{13} \mathrm{C} \mathrm{NMR}\left(\mathrm{CD}_{2} \mathrm{Cl}_{2}\right.$, $100 \mathrm{MHz}$; relative intensities in parentheses) $\delta 99.9$ (1.7), 113.7 (1.7), 126.8 (5.8), 127.8 (6.5), 128.1 (11.5), 128.4 (13.5), 128.5 (22.6), 128.9 (12.4), 129.3 (6.4), 129.7 (6.3), 129.8 (10.9), 131.5 (12.1), 133.5 (10.9), 134.2 (2.8), 136.7 (3.4), $138.4(2.8), 138.8$ (2.8), 160.2 (2.1), 160.9 (1.9), 162.2 (3.4), 165.1 (2.0); IR (KBr) 3325 (s, br) 1700 (vs, br) $1610 \mathrm{~m}, 1595 \mathrm{~m}, 1560 \mathrm{~m}, 1540 \mathrm{~m}, 1500 \mathrm{~s}$, 1460 vs, 1435 s, 1410 s, 1290 s, 1270 (s, br) cm ${ }^{-1}$; MS m/z 443 $\left(\left[\mathrm{M}^{+}+1\right], 9 \%\right), 442\left(\left[\mathrm{M}^{+}\right], 28 \%\right) ;$ HRMS calcd. for ${ }^{12} \mathrm{C}_{30} \mathrm{H}_{22} \mathrm{~N}_{2} \mathrm{O}_{2}$ $\mathrm{m} / \mathrm{z}$ 442.1681; found 442.1686 .

\section{Crystal data}

$\mathrm{C}_{30} \mathrm{H}_{22} \mathrm{~N}_{2} \mathrm{O}_{2}, M=442.50$, monoclinic, space group $P c, a=$ 11.209(3), $b=6.6731(8), c=16.500(4) \AA, \beta=108.47(2)^{\circ}, U=$ 1170.6(4) $\AA^{3}, Z=2, D_{\mathrm{c}}=1.255 \mathrm{~g} \mathrm{~cm}^{-3}, \mu=0.79 \mathrm{~cm}^{-1}, 2165$ unique reflections $\left(R_{\text {int }}=0.000\right), R_{1}=0.0409$ (for 927 observed data, $I>2 \sigma), w R_{2}=0.1210$ (all data).

\section{Acknowledgements}

This work was supported by the Australian Research Council (LG, PVB and CW) and the Deutsche Forschungsgemeinschaft (KPN and CW). We thank Dr. Holger Bornemann for the synthesis and spectroscopy of nitrile $\mathbf{1 8}$.

\section{References}

1 T. T. Tidwell, Ketenes, Wiley, New York, 1995; J. A. Hyatt and P. W. Raynolds, Org. React., 1994, 45, 159-646.

$\$$ CCDC reference number 233531. See http://www.rsc.org./suppdata/ $\mathrm{ob} / \mathrm{b} 4 / \mathrm{b} 412530 \mathrm{~d} /$ for crystallographic data in .cif format. 
2 C. Wentrup, W. Heilmayer and G. Kollenz, Synthesis, 1994, 12191248.

3 C. O. Kappe, G. Färber, C. Wentrup and G. Kollenz, J. Org. Chem., 1992, 57, 7078; G. Kollenz, S. Holzer, C. O. Kappe, T. S. Dalvi, W. M. F. Fabian, H. Sterk, M. W. Wong and C. Wentrup, Eur. J. Org. Chem., 2001, 57, 1315-1322.

4 D. M. Birney and P. E. Wagenseller, J. Am. Chem. Soc., 1994, 116, 6262-6270.

5 A. Stadler, K. Zangger, F. Belaj and G. Kollenz, Tetrahedron, 2001, 57, 6757-6763; B. C. Wallfisch, F. Belaj, C. Wentrup, C. O. Kappe and G. Kollenz, J. Chem. Soc., Perkin Trans. 1, 2002, 57, 599-605.

6 (a) A. B. Cheikh, J. Chuche, N. Manisse, J. C. Pomelet, K.-P. Netsch, P. Lorencak and C. Wentrup, J. Org. Chem., 1991, 56, 970-975; (b) H. J. Gordon, J. C. Martin and H. McNab, J. Chem. Soc., Perkin Trans. 1, 1984, 2129-2132; (c) H. Briehl, A. Lukosch and C. Wentrup, J. Org. Chem., 1984, 49, 2772-2779.

7 (a) B. E. Fulloon and C. Wentrup, J. Org. Chem., 1996, 61, 1363 1368; (b) J. J. Finnerty and C. Wentrup, J. Org. Chem., 2004, 69, 1909-1918.

8 V. V. Ramana Rao and C. Wentrup, J. Chem. Soc., Perkin Trans. 1, 1998, (16), 2583; C. Wentrup, V. V. Ramana Rao, W. Frank, B. E. Fulloon, D. W. J. Moloney and T. Mosandl, J. Org. Chem., 1999, 64(16), 3608-3619; V. V. Ramana Rao and C. Wentrup, J. Chem. Soc. Perkin Trans. 1, 2002, 64(11), 1332-1335; $N$-Arylimidoylketenes of type 4 are probably involved in the Conrad-Limpach synthesis of quinolones by pyrolysis of esters at ca. $250^{\circ} \mathrm{C} ; ; \mathrm{M}$. Conrad and $\mathrm{L}$. Limpach, Ber. Dtsch. Chem. Ges., 1887, 20(11), 944-1335; R. H. Reitsema, Chem. Rev., 1948, 43(11), 47-1335.

9 A. Maujean, G. Marcy and J. Chuche, Tetrahedron Lett., 1980, 519 522.

10 C. Zhou and D. M. Birney, J. Org. Chem., 2004, 69, 86-94.

11 R. K. Smalley, H. Suschitzky and E. M. Tanner, Tetrahedron Lett., 1960, 3465-3569.

12 H. Sheibani, R. Naduvile Veedu and C. Wentrup, unpublished results.
13 M. W. Wong and C. Wentrup, J. Org. Chem., 1994, 59, 5279-5285; J. Finnerty, J. Andraos, M. W. Wong, Y. Yamamoto and C. Wentrup, J. Am. Chem. Soc., 1998, 120, 1701-1704.

14 (a) C.O. Kappe, G. Kollenz and C. Wentrup, Chem. Commun. 1992, 485-486; (b) C.O. Kappe, G. Kollenz, R. Leung-Toung and C. Wentrup, Chem. Commun., 1992, 487-488; (c) C.O. Kappe, G. Kollenz, K.-P. Netsch, R. Leung-Toung and C. Wentrup, Chem. Commun., 1992, 489-490.

15 J. J. Finnerty and C. Wentrup, unpublished results, presented at the $3^{\text {rd }}$ Heron Island Conference on Reactive Intermediates and Unusual Molecules, Heron Island, Queensland, Australia, 17-23 July 2004.

16 (a) E. M. Kaiser, L. E. Solter, R. A. Schwarz, R. D. Beard and C. R. Hauser, J. Am. Chem. Soc., 1971, 93, 4237; (b) L. Aspart-Pascot and J. Lematre, Bull. Soc. Chim. Fr., 1971, 483; (c) A. Abbotto, S. Bradamante and G. A. Pagani, J. Org. Chem., 1993, 58, 449-455.

17 (a) C. Wentrup, H. Briehl, P. Lorencak, U.J. Vogelbacher, H.-W. Winter, A. Maquestiau and R. Flammang, J. Am. Chem. Soc., 1988 110, 1337-1343; (b) J. F. M. Oth and C. Wentrup, unpublished FVTmatrix isolation experiments, ETH Zurich, 1989.

18 M. T. Nguyen, T.-K. Ha and R. A. More O'Ferrall, J. Org. Chem., 1990, 55, 3251-3255; S. Ham and D. M. Birney, J. Org. Chem., 1996, 61, 3962-3968.

19 C. O. Kappe, M. W. Wong and C. Wentrup, J. Org. Chem., 1995, 60 1686-1695; A. Kuhn, C. Plüg and C. Wentrup, J. Am. Chem. Soc., 2000, 122, 1945-1948.

20 S. Ebner, B. Wallfisch, J. Andraos, I. Aitbaev, M. Kiselewsky, P. V. Bernhardt and C. Wentrup, Org. Biomol. Chem., 2003, 1, 2550-2555.

21 T. Eicher and G. Franke, Justus Liebigs Ann. Chem., 1981, 1337.

22 P. L. Julian, J. J. Oliver, R. H. Kimball, A. B. Pike and G. D. Jefferson, Org. Synth., Coll. Vol. II, 1943, 487-489.

23 L. J. Farrugia, J. Appl. Crystallogr., 1999, 32, 837.

24 G. M. Sheldrick, SHELX 97 - Programs for Crystal Structure Analysis (Release 97-2), Institut für Anorganische Chemie der Universität, Tamstrasse 4, D-3400 Göttingen, Germany, 1998

25 L. J. Farrugia, J. Appl. Crystallogr., 1997, 30, 565. 